\title{
Microbiology Of Nosocomial Infection In Tertiary Hospitals Of Dhaka City And Its Impact
}

\author{
${ }^{1}$ Md. Mohiuddin, ${ }^{2}$ J. Ashraful Haq, ${ }^{3}$ Md . Mozammel Hoq and ${ }^{4}$ Farida Huq

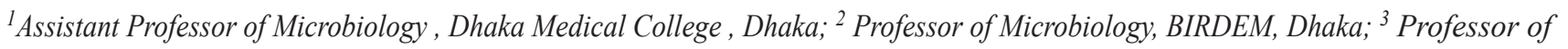 \\ Microbiology, Dhaka University, Dhaka; ${ }^{4}$ Senior Honorary Consultant (Microbiology), BIRDEM, Dhaka
}

\begin{abstract}
Nosocomial infection is an endemic problem encountered in hospitalized patients all over the world including Bangladesh. The present prospective study was carried out on 152 patients who were admitted in Dhaka Medical College Hospital and BIRDEM Hospital over a two years period to determine the organisms responsible for nosocomial infection, their antibiotic susceptibility pattern, sources and the impact of hospital infection on patient management.

Samples were collected from postoperative wounds, post catheterized urinary tract infection (UTI) and diabetic wounds. The patients without postoperative wound infection were taken as control group. To trace the sources of infection the samples from the different objects of the hospital environment were studied. The collected samples were cultured and isolated organisms were identified by colony morphology, gram staining and necessary biochemical tests. The identified organisms were tested for antibiogram pattern and plasmid profile.

The predominating organisms responsible for nosocomial infection were Esch.coli (55.9\%). The other organisms were Pseudomonas sp. (33.3\%), Proteus sp. (12.7\%), Staphylococcus aureus (5.9\%), Klebsiella sp. (4.9\%) and Acinatobacter sp. (3.9\%). The isolated organism showed high level of resistance to commonly used antibiotics. The resistance of the organisms markedly increased with the hospital stay. The hospital stay of the infected cases was significantly $(p<0.01)$ longer compared to non-infected cases. The cases which had infection with multiple organisms had longer hospital stay than that of cases infected with single organism. No clear association was observed between organisms isolated from hospital environment and infected cases. The study revealed the microbiology of hospital acquired infection in tertiary hospitals and its influence on patient management.
\end{abstract}

\section{Introduction}

Nosocomial infection (NI) is an emerging problem in hospital practice. The rate of NI varies from $9.2 \%$ to $21.4 \%$ in different countries of the world ${ }^{1}$. The rate of NI has been reported as $11.7 \%$ in Thailand, $17.0 \%$ in Ethiopia, $9.2 \%$ in UK and $9.0 \%$ in Norway. However, a few studies have been conducted in Bangladesh. A cross sectional study conducted in 1991 in the surgical wards of Dhaka Medical College Hospital showed that out of 240 patients, $72(38.0 \%$ ) suffered from NI of which $36.1 \%$ had wound infection and $23.6 \%$ had $\mathrm{UTI}^{2}$. Prevalence of NI in

Correspondence:

Dr. Md. Mohiuddin

Assistant Professor

Department of Microbiology

Dhaka Medical College

Mobile : 01711527736 post-operative patients was found to be higher $(49.0 \%)$ than preoperative patients (15.9\%).

Both Gram positive and Gram negative organisms play an important role in nosocomial infection. In bacterial analysis of hospital acquired infection, Ashraf et al.(1973) found that the predominant causative organisms for the post operative wounds were Esch. coli (37.5\%), Staph. aureus (21.7\%), Pseudomonas sp. (15.1\%), Streptococcus sp (8.4\%), Proteus sp. $(2.7 \%)$ in the surgery wards of Dhaka Medical College Hospital $^{3}$. Another study in 1992 involving eight medical college hospitals of Bangladesh, reported that the commonest organisms were Esch. coli (60\%) followed by Staph. aureus $(20 \%)$ in postoperative wound infections ${ }^{4}$. A study in a tertiary referral hospital in Dhaka revealed Staph. aureus $(42.0 \%)$ as the most frequently encountered pathogens among the non- 
hospitalized diabetic patients with wound infection while Gram negative organisms like Pseudomonas sp. (36.9\%), Esch coli (21.9\%), Proteus sp. (21.6\%). Klebsiella sp. (9.5\%) were most common in hospitalized diabetic patients ${ }^{5}$. Similar predominance of Gram negative organisms was found in hospital acquired UTI in other places ${ }^{6}$.

Antibiotic sensitivity pattern of organisms causing NI were generally resistant to first generation cephalosporins and betalactam antibiotics. Ahmed (1982) observed that there was a definite fall in the sensitivity of Esch. coli and Klebsiella sp. to ampicillin 7 . In USA, an increase in resistance to ciprofloxacin was observed among nosocomial pathogens especially Pseudomonas sp and Staph. aureus ${ }^{8}$. The increased resistance rate in organisms isolated from hospitalized patients was due to frequent use of antibiotics in hospitalized patients.

Therefore, the present study is an attempt to investigate the impact of nosocomial infection on hospital stay, the change of antibiotic sensitivity pattern of organisms in relation to the duration of stay in hospital and the possible source of infection in two tertiary care hospitals of Dhaka city.

\section{Materials and Methods}

Study population and sample collection

The clinical specimens for this study were collected from the selective patients admitted in Dhaka Medical College Hospital (DMCH) and Bangladesh Institute of Rehabilitation for Diabetes, Endocrine and Metabolic disorders (BIRDEM), Dhaka over a period of two years. Four categories of hospital admitted patients of different age and sex were included in this study namely:

a) Patients with post operative infections: Postoperative patients who developed pus or purulent discharge from operative wounds were selected for sample collection. The sample was collected from the operative wound area by sterile cotton swab on the first day of dressing (in between $5^{\text {th }}$ to $8^{\text {th }}$ postoperative day). A second sample was collected from the same wound 5 to 7 days after the first sample collection if the patients were available.

b) Patients with post catheterized urinary tract infections (UTI): Urine samples were collected aseptically from the patients who were catheterized after admission. $1^{\text {st }}$ sample was collected immediately after catheterization and $2^{\text {nd }}$ sample was collected at least 3 days after catheterization. Culture was done for both the samples. The cases which showed significant growth of bacteria in the $1^{\text {st }}$ sample were excluded from the study. The cases which showed either insignificant or no growth in $1^{\text {st }}$ sample but yielded significant growth in subsequent $2^{\text {nd }}$ sample were included in the study. c) Newly admitted diabetic patients with wound: Newly admitted diabetic patients with pre existing diabetic wound were considered as study population. $1^{\text {st }}$ sample was collected under aseptic condition from the diabetic wound immediately after admission with a sterile cotton swab stick. A second sample was collected from the same wound 5 to 7 days after the collection of the $1^{\text {st }}$ sample.

d) Post operative patients without wound infection: This group of postoperative patients manifested healed wounds. The non-infected group was included in this study to compare the impact of nosocomial infections in terms of hospital stay with postoperative infected patients.

\section{Sampling of environment and hospital personnel}

For detection of the sources of infection samples were collected from the different objects of hospital environment like dressing materials, OT table, floorofOTandwards, bed sheets, instruments of operation theatre as described elsewhere ${ }^{9,10}$. Air sampling from operation theatre and wards was also done by settling plated technique. One blood agar and one MacConkey agar plate were exposed for 30 minutes in the operation theatre during operation and in the ward during dressing of the wound of the patients. The plates were then brought immediately for incubation.

Samples were also collected from nasal cavity, nail folds, inter digital spaces and palms of ward and OT personnel (Doctors, Nurses and ward boys).

\section{Microbiological methods}

The organisms were isolated from the specimen by inoculation and subculture on blood agar and MacConkey agar media. Identification of the organisms was done by colony morphology, Gram staining and standard biochemical tests.

All the isolates were tested for sensitivity against antimicrobial agents like ampicilin (AM), co-trimoxazole (TS), cephalexin (CFX), tetracycline (T), ceftriaxone (CRO), ceftazidime (CAZ), ciprofloxacin (CIP), gentamicin (GM) by disc diffusing method of Kirby Bauer et al. ${ }^{11}$. The potency of each batch of disc was standardized by the reference strain of ATCC Esch. coli, No 25922 and Pseudomonas aeruginosa No 27853. Zone of inhibition were compared with the standard value and was considered as sensitive (S), moderately sensitive (M) and resistant (R) according to the NCCLS (1998) ${ }^{12}$.

\section{Preservation of organisms}

All the isolates were preserved in 15\% glycerol broth and stored at $-20^{0} \mathrm{C}$ for plasmid profile analysis.

Extraction and analysis of plasmid DNA

Plasmid profile analysis (PPA) was done to determine the possible sources of nosocomial infections. The plasmid was 
extracted from Esch. coli, Pseudomonas sp. and Klebsiella sp. which were isolated from the patients and from the hospital environment by Miniprep method ${ }^{13}$. The extracted plasmid DNA was then analyzed by agarose gel electrophoresis. A standard curve was drawn by plotting the mobility of plasmid DNA along the $\mathrm{X}$ axis and its molecular weight along the $\mathrm{Y}$ axis. The molecular weights of the unknown plasmids were determined from this curve

\section{Data management and analysis}

The collected data were checked, verified and edited daily. The data were coded and entered into computer by using SPSS data entry II program. Statistical significance was tested with appropriate tests.

\section{Results}

A total of 102 infected cases having different categories of infections and 50 postoperative non-infected cases as control were studied. Out of 102 infected cases, 74(48.7\%) had postoperative infection, $16(10.5 \%)$ had post catheterized UTI and the remaining $12(7.9 \%)$ patients had diabetic wound infection (Table I). Among the postoperative cases, laparotomy cases topped the list of performed operation (33.9\%), followed by caesarean section (17.7\%), appendisectomy $(14.15 \%)$, inguinal herniorrhaphy $9(7.2 \%)$ and wound toileting $7(5.6 \%)$. Other operations were fistulectomy $4(3.2 \%)$, plastic surgery $3(2.4 \%)$, amputation 2(1.6), mastectomy 2(1.6), cystostomy $1(0.8 \%)$, sequestrecstomy $1(0.8 \%)$, nephrostomy $1(0.8 \%)$.

It was observed that out of 42 laparotomy cases, 26(61.9\%) had postoperative wound infection. In case of appendisectomy, inguinal herniorrhaphy, cholecystectomy postoperative infected and non-infected cases were $2(11.1 \%)$ vs $16(88.9 \%), 1(11.1 \%)$ vs $8(88.9 \%), 1(14.3 \%)$ vs $6(85.7 \%)$ respectively.

Table I: Categories study population $(n=152)$

\begin{tabular}{|c|c|c|}
\hline Categories of cases & Number of Patients & Percentage \\
\hline \multicolumn{3}{|l|}{ Patients with postoperative } \\
\hline Surgical wound infection & 74 & 48.7 \\
\hline \multicolumn{3}{|c|}{ Patients with post catheterized } \\
\hline urinary tract infection+ & 16 & 10.5 \\
\hline \multicolumn{3}{|l|}{ Patients with diabetic wound } \\
\hline infection & 12 & 7.9 \\
\hline Total & 102 & 67.1 \\
\hline \multicolumn{3}{|c|}{ Patients without postoperative } \\
\hline wound infection & 50 & 32.9 \\
\hline Total & 152 & 100.0 \\
\hline
\end{tabular}

Table-II shows the rate of isolation of organisms from different types of infection. Each. coli was the predominating organisms in cases of postoperative wound infection (56.7\%) and post catheterized urinary tract infection $(68.7 \%)$. This was followed by Pseudomonas sp. which was $27.0 \%$ in case of postoperative wound infection and $18.7 \%$ in case of post catheterized UTI while in diabetic wound infection, Pseudomonas sp. was the predominatingorganism(91.7\%)followed by Esch.coli(33.3\%).

Table II: Categories of study population and organisms isolated from different types of infections

\begin{tabular}{|c|c|c|c|c|c|c|c|c|}
\hline \multirow[t]{2}{*}{$\begin{array}{l}\text { Organisms } \\
\text { isolated }\end{array}$} & \multicolumn{2}{|r|}{$\begin{array}{c}\text { Post } \\
\text { operative } \\
\text { wound } \\
\text { infection } \\
(n=74)\end{array}$} & \multicolumn{2}{|c|}{$\begin{array}{c}\text { Post } \\
\text { catheterized } \\
\text { UTI } \\
(n=16)\end{array}$} & \multicolumn{2}{|c|}{$\begin{array}{l}\text { Diabetic } \\
\text { wound } \\
\text { infection } \\
(n=12)\end{array}$} & \multicolumn{2}{|c|}{$\begin{array}{c}\text { Total } \\
(n=102)\end{array}$} \\
\hline & No & $\%$ & No & $\%$ & No & $\%$ & No & $\%$ \\
\hline Esch.coli & 42 & 56.7 & 11 & 68.7 & 4 & 33.3 & 57 & 55.9 \\
\hline Pseudomonas sp. & 20 & 27.00 & 3 & 18.7 & 11 & 91.7 & 34 & 33.3 \\
\hline Proteus sp. & 10 & 13.5 & 1 & 6.2 & 2 & 16.7 & 13 & 12.7 \\
\hline Staph. aureus & 6 & 8.0 & 0 & 00.0 & 0 & 00.0 & 6 & 5.9 \\
\hline Klebsiella sp. & 4 & 5.4 & 1 & 6.2 & 0 & 00.0 & 5 & 4.9 \\
\hline Acinetobacter sp. & 3 & 4.0 & 1 & 6.2 & 0 & 00.00 & 4 & 3.9 \\
\hline
\end{tabular}

Note: Multiple organisms isolated from one sample; Various species of differentorganisms isolatedwere:Pseudomonasaeruginosa $=30$, Paeudomonas flusrescens =2, Pseudomonas cepacia $=2$, Proteus mirabilis=10, Proteus vulgaris $=3$, Klebsiella pneumonae $=3$, Klebsiella oxytoca $=1$, Acinetobacter $\mathrm{sp}=4$

Table-III shows the antibiotic resistance pattern of major organisms isolated from the 1 st and 2 nd samples of different categories infected cases. It was observed that ampicillin was resistant to $100 \%$ of Esch. coli isolated from the 1 st and 2 nd sample. It was also observed that susceptibility of Esch. Coli to other antibiotics markedly reduced in 2 nd samples. There was significant increase $(\mathrm{p}<0.01)$ of resistance to ceftriaxone ( $66.6 \%$ to $87 \%$ ), ceftazidime (56.1\% to $82.2 \%$ ), ciprofloxacin (77.2\% to 100.00$)$ and gentamicin $(80.8 \%$ to $100 \%)$ in 2 nd samples. But no significant ( $p>0.05$ ) change of resistance was found between 1 st and 2nd samples to ampicillin, cephalexin, tetracycline and cotrimoxazole. Similarly, resistance of Pseudomonas sp and Proteus sp to all the used antibiotics increased in 2nd samples. 
Table III: Resistance pattern of major organisms isolated from the $1^{\text {st }}$ and $2^{\text {nd }}$ samples of the different categories of infected cases

\begin{tabular}{|c|c|c|c|c|c|c|}
\hline \multirow[t]{2}{*}{$\begin{array}{l}\text { Name of } \\
\text { Antibiotics }\end{array}$} & \multicolumn{2}{|c|}{$\begin{array}{c}\text { No of } E \text {. coli } \\
\text { resistant }\end{array}$} & \multicolumn{2}{|c|}{$\begin{array}{l}\text { No. of } \\
\text { Pseudomonas } \\
\text { resistant }\end{array}$} & \multicolumn{2}{|c|}{$\begin{array}{l}\text { No. of } \\
\text { Proteus } \\
\text { resistant }\end{array}$} \\
\hline & $\begin{array}{c}1^{\text {st }} \\
\text { sample }\end{array}$ & $\begin{array}{c}2^{\text {nd }} \\
\text { sample }\end{array}$ & $\begin{array}{c}1^{\text {st }} \\
\text { sample }\end{array}$ & $\begin{array}{c}2^{\text {nd }} \\
\text { sample }\end{array}$ & $\begin{array}{c}1^{\text {st }} \\
\text { sample }\end{array}$ & $\begin{array}{c}2^{\text {nd }} \\
\text { sample }\end{array}$ \\
\hline & $(\mathrm{n}=57)$ & $(n=23)$ & $(n=34)$ & $(\mathrm{n}=25)$ & & \\
\hline Ampicillin & $\begin{array}{c}57 \\
(100.0)\end{array}$ & $\begin{array}{c}23^{*} \\
(100.0)\end{array}$ & $\begin{array}{c}34 \\
(100.0)\end{array}$ & $\begin{array}{c}25^{*} \\
(100.0)\end{array}$ & $\begin{array}{c}11 \\
(84.6)\end{array}$ & $\begin{array}{c}9 * \\
(80.0)\end{array}$ \\
\hline Cephalexin & $\begin{array}{c}49 \\
(85.9)\end{array}$ & $\begin{array}{c}23^{*} \\
(100.0)\end{array}$ & $\begin{array}{c}33 \\
(94.1)\end{array}$ & $\begin{array}{c}25^{*} \\
(100.0)\end{array}$ & $\begin{array}{c}10 \\
(51.5)\end{array}$ & $\begin{array}{c}8^{*} \\
(60.0)\end{array}$ \\
\hline Ceftriaxone & $\begin{array}{c}38 \\
(66.6)\end{array}$ & $\begin{array}{l}20 * * \\
(87.0)\end{array}$ & $\begin{array}{c}22 \\
(47.1)\end{array}$ & $\begin{array}{c}22 * \\
(64.0)\end{array}$ & $\begin{array}{c}4 \\
(30.8)\end{array}$ & $\begin{array}{c}6 * \\
(60.0)\end{array}$ \\
\hline Ceftazidime & $\begin{array}{c}32 \\
(56.1)\end{array}$ & $\begin{array}{l}20 * * \\
(82.2)\end{array}$ & $\begin{array}{c}17 \\
(50.4)\end{array}$ & $\begin{array}{c}16^{*} \\
(40.0)\end{array}$ & $\begin{array}{c}3 \\
(15.4)\end{array}$ & $\begin{array}{c}6^{*} \\
(40.0)\end{array}$ \\
\hline Tetracycline & $\begin{array}{c}51 \\
(89.5)\end{array}$ & $\begin{array}{c}23 * \\
(100.0)\end{array}$ & $\begin{array}{c}31 \\
(85.3)\end{array}$ & $\begin{array}{c}25^{*} \\
(100.0)\end{array}$ & $\begin{array}{c}12 \\
(92.3)\end{array}$ & $\begin{array}{c}10 * \\
(100.0)\end{array}$ \\
\hline Contrimoxazole & $\begin{array}{l}\text { le } 51 \\
(89.5)\end{array}$ & $\begin{array}{c}23 * \\
(100.0)\end{array}$ & $\begin{array}{c}31 \\
(88.2)\end{array}$ & $\begin{array}{c}25^{*} \\
(100.0)\end{array}$ & $\begin{array}{c}10 \\
(76.9)\end{array}$ & $\begin{array}{c}8^{*} \\
(70.0)\end{array}$ \\
\hline Ciprofloxacin & $\begin{array}{c}44 \\
(77.2)\end{array}$ & $\begin{array}{c}23 * * \\
(100.0)\end{array}$ & $\begin{array}{c}23 \\
(58.8)\end{array}$ & $\begin{array}{l}23^{* *} \\
(92.0)\end{array}$ & $\begin{array}{c}7 \\
(53.8)\end{array}$ & $\begin{array}{c}7 * * \\
(70.0)\end{array}$ \\
\hline Gentamicin & 46 & $23 * *$ & 22 & $17 *$ & 5 & $7 *$ \\
\hline
\end{tabular}

$* \mathrm{p}>0.05, * * \mathrm{p}<0.05$ compared between $1^{\text {st }}$ and $2^{\text {nd }}$ samples; Figures in parenthesis indicate percentage.

Table-IV and V shows antibiotic resistance pattern of Esch. coli andPseudomonas spisolated frompostoperative infected wounds, post catheterised UTI and diabetic wounds. It was found that resistance pattern of Esch. coli isolated from different sites of infection were dissimilar. Esch. coli isolated from diabetic wound infections showed the highest resistance to cephalexin $(100 \%)$ followed by ceftriaxone $(75 \%)$ ciprofloxacin $(75 \%)$ ceftazidime (50\%) and gentamincin (50\%). However, Esch.coli isolated from postoperative wound infections showed lower rate of resistance to all the used antibiotics. Pseudomonas sp. isolated from the post catheterized UTI showed the highest resistance to cephalexin (100\%) followed by ceftrioxone $(66.7 \%)$ and ciprofloxcin (66.7\%). The rate of resistance of Pseudomonas sp. isolated from the post operative wound infection ranged between $30-85 \%$ to various antibiotics.
Table IV : Antibiotic resistance pattern of Esch. coli isolated from different sites of infection

\begin{tabular}{|c|c|c|c|c|c|c|}
\hline \multirow{2}{*}{$\begin{array}{l}\text { Sites of } \\
\text { infection }\end{array}$} & \multirow{2}{*}{$\begin{array}{c}\text { No. } \\
\text { of } \\
\text { iso }\end{array}$} & \multicolumn{5}{|c|}{ Antibiotics } \\
\hline & & $\begin{array}{l}\text { Cepha } \\
\text { lexin }\end{array}$ & $\begin{array}{l}\text { Ceftria } \\
\text { xone }\end{array}$ & $\begin{array}{l}\text { Ceftaz } \\
\text { idime }\end{array}$ & $\begin{array}{l}\text { Ciprof } \\
\text { loxacin }\end{array}$ & $\begin{array}{l}\text { Genta } \\
\text { micin }\end{array}$ \\
\hline & \multicolumn{6}{|c|}{ ates } \\
\hline Post operative & \multirow[t]{2}{*}{42} & 29 & 14 & 7 & 28 & 24 \\
\hline wound infection & & $(69.0)$ & $(33.3)$ & $(16.0)$ & $(66.7)$ & $(57.1)$ \\
\hline Post catheterized & \multirow[t]{2}{*}{11} & 10 & 8 & 7 & 9 & 9 \\
\hline UTI & & $(90.9)$ & $(72.7)$ & $(63.6)$ & $(81.8)$ & $(81.8)$ \\
\hline \multirow{2}{*}{$\begin{array}{l}\text { Diabetic wound } \\
\text { infections }\end{array}$} & \multirow[t]{2}{*}{4} & 4 & 3 & 2 & 3 & 2 \\
\hline & & $(100.0)$ & $(75.0)$ & $(50.0)$ & $(75.0)$ & $(50.0)$ \\
\hline \multicolumn{7}{|c|}{ Figures in parenthesis indicate percentage } \\
\hline \multicolumn{7}{|c|}{$\begin{array}{l}\text { Table V: Antibiotic resistance pattern of Pseudomonas sp. isolated from differe } \\
\text { sites of infection }\end{array}$} \\
\hline \multirow{4}{*}{$\begin{array}{l}\text { Sites of } \\
\text { infection }\end{array}$} & \multirow{3}{*}{$\begin{array}{c}\text { No. } \\
\text { of } \\
\text { iso }\end{array}$} & \multicolumn{4}{|c|}{ Antibiotics } & \multirow{3}{*}{$\begin{array}{l}\text { Genta } \\
\text { micin }\end{array}$} \\
\hline & & Cepha & Ceftria & Ceftaz & Ciprof & \\
\hline & & lexin & xone & idime & loxacin & \\
\hline & \multicolumn{2}{|l|}{ ates } & & & & \\
\hline \multirow{2}{*}{$\begin{array}{l}\text { Post operative } \\
\text { wound infection }\end{array}$} & \multirow[t]{2}{*}{20} & 17 & 6 & 7 & 9 & 8 \\
\hline & & $(85.0)$ & $(30.0)$ & $(35.0)$ & $(45.0)$ & $(40.0)$ \\
\hline \multirow{2}{*}{$\begin{array}{l}\text { Post catheterized } \\
\text { UTI }\end{array}$} & \multirow[t]{2}{*}{3} & 3 & 2 & 1 & 2 & 1 \\
\hline & & $(100.0)$ & $(66.7)$ & (33.3) & $(66.7)$ & (33.3) \\
\hline Diabetic wound & 11 & 10 & 5 & 1 & 7 & 5 \\
\hline 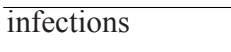 & & $(90.9)$ & $(45.5)$ & $(9.1)$ & (63.6) & $(45.5)$ \\
\hline
\end{tabular}

Note: Pseudomonas species included all the species isolated as mentioned in table- 2 . Figures in parenthesis indicate percentage.

Table VI: Rate of isolation of single and multiple organisms from different types of infection

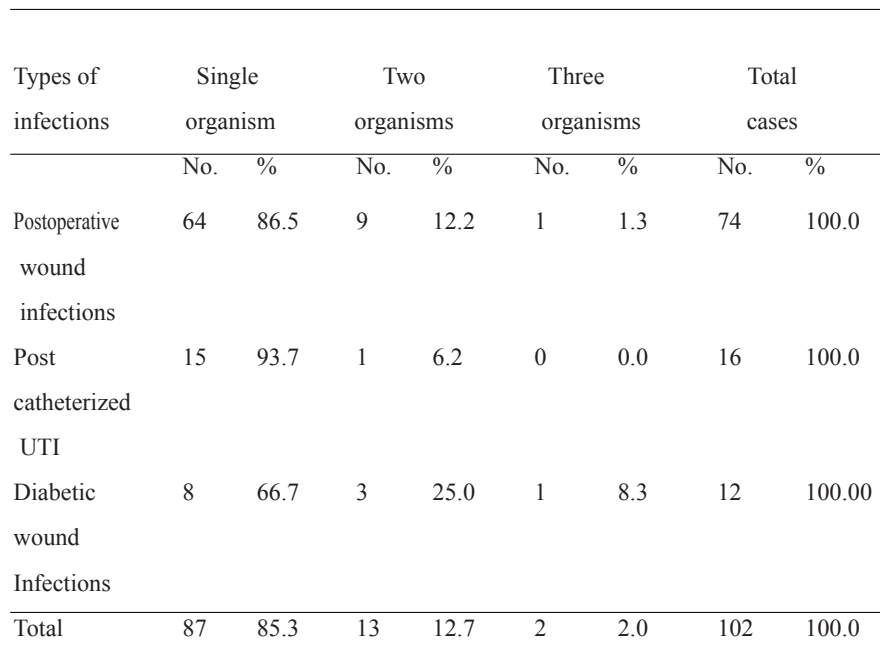


Table-VI shows the involvement of single and multiple types of organisms on the causation of infection. It was observed that $85.3 \%$ infection was caused by single organism, while $12.7 \%$ was caused by two types of organisms and only $2.0 \%$ of infection was caused by three types of organisms. About $33 \%$ diabetic wound infection was due to multiple organisms.

Table VII: Relationship between type of infection and duration of hospital stay

\begin{tabular}{lcc} 
Category of & No. of cases & Mean duration of hospital \\
\hline patients & 74 & stay (days) \\
Postoperative wound infection & 16 & $23.9 \pm 14.3$ \\
Post catheterized UTI & 12 & $19.9 \pm 10.1$ \\
Diabetic wound infection & 50 & $26.1 \pm 9.9$ \\
Postoperative non-infected cases (control) & 87 & $9.5 \pm 6.1$ \\
Infected with Single organism & & $21.8 \pm 10.8$ \\
\hline
\end{tabular}

Note: Mean duration of hospital stay of all infected cases was

$23.5 \pm 13.3$ days; $\mathrm{p}<0.01$, compared between infected and non-infected control,

$\mathrm{p}>0.05$, compared between infected with single and multiple organisms group

Table-VII shows the duration of hospital stay of infected and non-infected cases. The mean duration of hospital stay of all infected patients was significantly longer $(23.5+13.3$ days $)$ than that of postoperative non-infected patients $(9.5+6.1$ days). Also, the mean duration of hospital stay of each category of patients with infection was longer than postoperative noninfected cases. There was no significant differerences between the mean duration of hospital stay of patients infected with multiple organisms compared to that of single organism $(33.5+20.6$ days vs $21.8+10.8$ days $)$.

Table VIII: Relationship between type of infecting organisms and duration of hospital stay

Fypes of Organisms No. Nean duration of stay (days)

$\begin{array}{lcc}\text { Esch. Coli } & 49 & 21.2 \pm 9.1^{\mathrm{a}} \\ \text { Pseudomonas sp. } & 21 & 18.7 \pm 8.7^{\mathrm{a}} \\ \text { Mixed organisms* } & 15 & 33.5 \pm 20.6 \\ \text { Other organisms** } & 17 & 27.4 \pm 14.1 \\ \text { Non-infected Group } & 50 & 9.5 \pm 6.1\end{array}$

Note: * Mixed organisms include Esch. coli. Pseudomonas sp. Proteus sp,

**Other organisms include S. aureus, Klebsiella sp., Acinetobacter sp.

$\mathrm{a}=\mathrm{p}<0.05$, compared between infected with respective organism and non-infected

control

$\mathrm{p}>0.05$, compared between mixed organisms and non-infected control
Table-VIII shows the relationship between type of infecting organisms and duration of hospital stay. The mean duration of hospital stay of patients infected with differenttypes of organisms ranged between 18-33 days compared to non-infected group. Though the longest duration of hospital stay was $33.5+20.6$ days for infections caused by mixed organisms (Esch. coli + Pseudomonassp. + Proteussp.)thedifferencewasnotstatistically significant $(\mathrm{p}>0.05)$ when compared with cases infected with other organisms.

Organisms isolated from hospital environment, various hospital objects and personnel are shown in Table-IX. Various Gram negative and positive organisms were isolated from OT air, table, floor, tap water, distal end of suction tube and ward floor. Nasal cavity, palm, nail bed and inter digital spaces of the OT and ward personnel yielded Strep. viridans.

The molecular weight and the number of extracted plasmid DNA of the representative isolates of the patients and the hospital environment was shown in Table-X. The number of plasmid DNA and its corresponding molecular weight were also compared. The pattern of plasmid DNA of the patient and that of the hospital environment was dissimilar.

Table IX: Organisms isolated from different objects in hospital environment

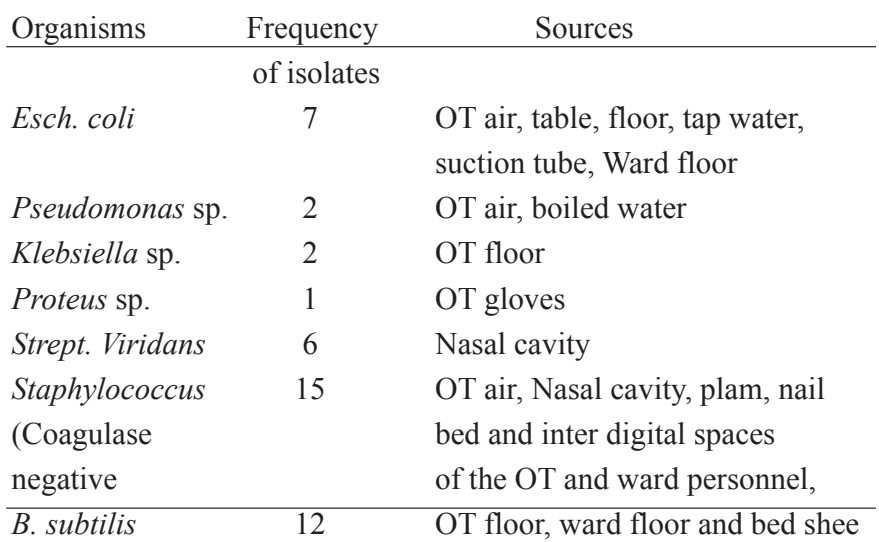

Table X: Plasmid profile of the selected organism isolated from patients and hospital environment

\begin{tabular}{|c|c|c|c|c|c|c|c|c|c|}
\hline \multicolumn{5}{|c|}{ Organisms isolated from the patients } & \multicolumn{5}{|c|}{$\begin{array}{c}\text { Organisms isolated from the hospital } \\
\text { environment }\end{array}$} \\
\hline $\begin{array}{l}\text { SP } \\
\text { No } \\
\text {. }\end{array}$ & Organisms & Source & No. & $\begin{array}{c}\text { Plasmid } \\
\text { MW } \\
(\mathrm{mDa})\end{array}$ & $\begin{array}{l}\text { SP } \\
\text { No. }\end{array}$ & Organisms & Source & & $\begin{array}{l}\text { Plasmid } \\
\text { Mol. wt. } \\
(\mathrm{mDa})\end{array}$ \\
\hline 59 & $\begin{array}{l}\text { Klebsiella } \\
\text { sp. }\end{array}$ & Wound & 1 & 26.7 & OT & $\begin{array}{c}\text { Klebsiella } \\
\text { sp. }\end{array}$ & $\begin{array}{l}\text { OT } \\
\text { Floor }\end{array}$ & 3 & $\begin{array}{l}18.7,8,6 \\
7\end{array}$ \\
\hline 63 & Esch. coli & Wound & 2 & $\begin{array}{l}28 \\
16.7\end{array}$ & OT & Esch. coli & $\begin{array}{c}\text { OT } \\
\text { table }\end{array}$ & 4 & $\begin{array}{l}28,25,3 \\
16,7,5 \cdot 3\end{array}$ \\
\hline
\end{tabular}




\section{Discussion}

Nosocomial infection is a problem affecting the hospitalized patients both in developed and developing countries. In developed countries many interventions were made to control nosocomial infection. But in developing countries like Bangladesh no emphasis has yet been given in this field. In different situations and perspective the pattern of nosocomial infections is different. In the present study, an attempt was made to explore the pattern of organisms responsible for hospital acquired infection in large hospitals of Dhaka city. The antibiogram pattern of the offending organisms and the probable sources of infection were also investigated. In this study, it was observed that the most common infective organism was Esch. coli (55.9\%) followed by Pseudomonas Sp. (33.3\%) and peroteus sp. (12.7\%). In an earlier study in Bangladesh in 1973, reported similar predominance of Esch. Coli (37.5\%) in hospital aquired wound infection ${ }^{3}$.

Another study in Bangladesh in 1992, showed that Esch. coli was the major pathogen $(60.0 \%)$ in the postoperative infection followed by Staph. aureus ${ }^{4}$. Similar predominance of Esch. coli and other Gram negative organisms were reported in hospital acquired infection in Canada ${ }^{14}$. However Aman (1982) in Lahore found that the predominating causative organism of surgical infection was Staph. aureus (28.6\%) followed by Esch. coli $(24.7 \%)$ and Pseudomonas Sp. $(23.7 \%)^{15}$. The isolation rate of different organisms varied in different clinical samples. In the present study Esch. coli was the predominating organisms in post operative infection and UTI, while Pseudomonas sp. was the predominating organism in the diabetic wound. Similarly many studies in Bangladesh and other countries showed different isolation rate in different clinical samples. But in diabetic wounds pseudomonas sp. was the offending organism (91.7\%) followed by Esch. coli (33.3\%). In Bangladesh, Jinnah et al., (1998) reported that Pseudomonas sp. was the major isolate from the patients with diabetic wound infection ${ }^{5}$. However, the isolation rate of Pseudomonas sp. was much less (36.9\%) as compared to the present study. This difference in rate might be due to small sample size or difference in sample selection procedure. The variation in the isolation of organisms by various workers in the same or in different localities over time might be due to use of different antibiotics and the elimination of susceptible organismsbytheantibioticresistantorganismslikePseudomonas sp. and Proteus $^{16}$.

The high rate of antibiotic resistance of isolated organisms in our study might be due to wide spread use of antibiotics in our hospitals. The antibiogram pattern of the organisms isolated from the first samples was also compared with the second samples collected 5 to 7 days later. It was observed that $100.0 \%$ of Esch. coli was resistant to ampicillin in both first and second samples. There was significant increase in resistance to ceftriaxone (from 66.6 to $87 \%, \mathrm{p}>0.01$ ), ceftazidime (from 56.1 to $82.2 \%, \mathrm{p}<0.02$ ), ciprofloxacin (from 77.2 to $100.0 \%$, $\mathrm{p}<0.005$ ) and gentamicin (from 80.8 to $100 \%, \mathrm{p}<0.008$ ). In case of Pseudomonas sp. and Proteus sp. a marked increase in resistance to antibiotics were also observed. Resistance rate highly increased in $2^{\text {nd }}$ samples in case of both the organisms. It was also observed that resistance rate of $S$. aureus was relatively lower than that of Gram negative organisms. This higher resistance in Gram negative organisms might be due to the production of extended spectrum beta-lactamases by Gram negative organisms ${ }^{17}$. Increased level of resistance in hospital isolates was also reported to the commonly used antibiotics by others ${ }^{4,5,6,8}$. We have noted that the resistance of isolated organisms to the prescribed antibiotics ranged from $62-100 \%$. In this study it was observed that single type of organism was the common cause of infection in majority of cases. About 15 $\%$ of infection was caused by multiple organisms. In an earlier study, Shaw et al., (1973) showed that out of 204 infected cases $86.3 \%$ was caused by single organism and the remaining $13.7 \%$ was caused by mixed organisms ${ }^{18}$. This higher rate of infection with single organism could be due to difference in site of operation. The duration of the hospital stay was profoundly influenced by the infections. The hospital stay of the infected cases was significantly longer compared to non-infected cases. However, the cases which had infection with more that one or mixed organisms had longer hospital stay than that of cases infected with single organism.

In this study different organisms were isolated from different objects of the hospital environment. It was found that Esch. coli was the major isolates from the OT air, table, floor, tap water, suction tube and ward floor. Pseudomonas sp. was isolated from OT air and boiled water. Klebsiella sp. was isolated from OT floor and Proteus sp. was isolated from OT gloves. The isolated organisms from the possible sources showed a wide range of resistance to the antibiotics used in the hospital. An attempt was made to trace the sources of nosocomial infection. In this regards, plasmid profile analysis (PPA) was carried out with the representative organisms isolated from the different objects and hospital staffs with those of wound samples of the study population. It was observed that plasmid profile of the isolates of the probable sources was not of similar to those of wound samples. Though sources of nosocomial infection could not be traced by PPA, it was evident that Esch.coli, Pseudomonas sp, Proteus sp, Klebsiella $\mathrm{sp}$. isolated from the different objects of hospital environment might be a potential source of nosocomial infection. 


\section{References}

1. Mayonwhite, R.T., G. Ducel and T. Kereselidge, et al., . An international survey of the prevalence of hospital acquired infection. J. Hosp. Infection 1988; 11:43-48.

2. Hussain, T., M.A. Fazal, and A. Ahmed, et al.,. Nosocomial infection-A cross-sectional study in the surgical wards of Dhaka Medical College Hospital. J. of Preventive and Social Med.1991; 10(2): 10-13.

3. Ashraf, S.A. and Prodhan A.. Study of pattern of infections in the surgical wounds of DMCH. Bangladesh Med. Journal 1973;I: 105-110.

4. Zaman MA, Ahmed ANN, and Chowdhury MZU et al., Surveillance study of Hospital acquired infection. J of Bangladesh College of Physicians and Surgeons 1992;10 (1): 9-13.

5. Jinnah, F., Morshed MG and Huq F. Multi resistant staphylococcus aureus isolated from wound swab of diabetic patients. Journal of Infectious Diseases and Antimicrobial agents 1998;15 (1): 15-18;

6. Sharafi R., Geckler R. and Child S. Treatment of urinary tract infection: selecting an appropriate broad-spectrum antibiotic for nosocomial infection., Am. J. Med. 1966; 100(6A): 765-825.

7. Ahmed SI. Antibacterial sensitivity pattern in urinary tract infection 1975-1979; JPMA 1982 (March): 69-71.

8. Coronado VS., Edwards JR., Culver DH. and Gynes RO. Ciprofloxacin resistance among nosocomial Pseudomonas aeruginosa and staphylococcus aureus in the United States. Infection controls Hosp. Epidemiol 1995; 16 (2): 71-75.

9. Pelezar Jr. MJ,. Chan ECS, Crieg NR. Microbiology. $5^{\text {th }}$ end. Tata McGraw-Hill publishing Co. Ltd. New Delhi. 1994.

10. Weissfeld AS, Nosocomial infection and hospital epidemiology. In: Sonnenwirth ACL. Jarrat( editors). Gradwohl's clinical laboratory methods and diagnosis, $8^{\text {th }}$ end. Louis ST: The CV. Mosby company 1980: p1971-77.

11. Bauer A, Kirby WMM., Sherries JC and Turck M. Antibiotic susceptibility testing by standardized single disc method. Am. J. Clin. Pathol.1966; 45(5):493-96.

12. Approved Standard NCCLS Doc M 7-A4: Methods for antimicrobial susceptibility tests for bacteria that grow aerobically. (4 ${ }^{\text {th }}$ edn) Villanova, PA: National committee for clinical Laboratory Standards. 1998.

13. Fredrick M., Ausubel R, Brent, et al. Short protocols in molecular biology ( $3^{\text {rd }}$ edn): John wiley and sons, Inc., USA 1995; 2-11.

14. Westwood JCN, Legace S and Mitchell MA. Hospital acquired infection: Present and future impact and needs for positive action. CMA J. 1974(April). 6; 110: 769774.

15. Aman S. Bacteriological Analysis of wound Infection in Mayo Hosptial, Lahore, JPMA 1982 (March); 66-68.

16. Baqui A. Bacterial etiology of CSOM with particular emphasis on Pseudomonas aeruginosa, M. phil Thesis. 1986; University of Dhaka.

17. Pitout JDD, Thomson KS and Hanson ND et al. Beta Lactamases responsible for resistant to expanded-spectrum cephalosporin in Klebsiella pneumoniae, Esch. coli and Proteus mirabilis isolates recovered in south Africa. Antimicrobial agents and chemotherapy 1998; 42(6): 1350-54.

18. Shaw DC, Doig M and Douglas D. Is air bornce infection on operating theatres an important cause of wound infection in general surgery: Lancet 1973 (January); 6: 17-20. 